\title{
22. SOURCES OF MIOCENE, PLIOCENE, AND PLEISTOCENE SILICICLASTIC SEDIMENTS IN UNIT I, SITES 612 AND 6131
}

\author{
Jim Mazzullo, Department of Geology, Texas A\&M University²
}

\begin{abstract}
The sources of siliciclastic sediments for the upper Miocene through Pleistocene sediments of Unit I (Sites 612 and 613) were determined by grain-shape and surface-texture analyses. Two types of quartz grain shapes were present in these samples. One type, characterized by well-rounded quartz grains with surficial weathering features, represents clastic sediments derived from Cretaceous and Tertiary strata on the New Jersey continental margin. The second, characterized by angular grains with inherited overgrowth features, represents clastic sediments derived from the pre-Cenozoic sedimentary and crystalline rocks of the Appalachian Province.

The distribution of these two grain-shape types throughout the sediments of Unit I shows that a drastic change in source for the New Jersey continental margin occurred some time in the Pleistocene. Before this time, the major source of sediment was the Appalachian Province, as indicated by high proportions of the second grain-shape type. After this time, the major source was the Cretaceous and Tertiary sediments of the New Jersey continental margin, as indicated by high proportions of the first grain-shape type. From this pattern, it is concluded that during the late Miocene and Pliocene a large river which drained the Appalachian Province served as the major conduit for sediment to the New Jersey continental margin. At some time during the Pleistocene, however, the depositional basin for this river shifted away from this area, and most of the sediment supplied thereafter was derived from more local Cretaceous and Tertiary strata.
\end{abstract}

\section{INTRODUCTION}

Leg 95 of the Deep Sea Drilling Project recovered cores from Sites 612 and 613 on the New Jersey continental margin. At Site 612, drilled on the upper slope, approximately $135 \mathrm{~m}$ of siliciclastic-rich sediments of late Miocene(?) through Pleistocene age were recovered. These sediments, which constitute lithologic Unit I, have been subdivided into three parts: a lower subunit, IC, composed of dark gray to olive gray muds; a middle subunit, IB, composed of alternating beds of mud and glauconitic-quartzose sand; and an upper subunit, IA, composed of dark gray and reddish gray muds.

A similar sequence of siliciclastic-rich upper Miocene through Pleistocene sediments was recovered from Site 613 , drilled on the adjacent continental rise. These Unit I sediments, about $270 \mathrm{~m}$ thick at this location, can also be subdivided into three parts: a lower subunit, IC, composed of yellow green siliceous muds rich in nannofossils; a middle subunit, IB, composed of greenish gray siliciclastic and calcareous mud with occasional beds of glauconitic silty sand; and an upper subunit, IA, composed of interbedded mud, marly nannofossil and/or diatomaceous ooze, and glauconitic-quartzose sand and silt.

The sediments of Unit I represent a radically different depositional regime from that which resulted in the deposition of the underlying Cretaceous through Oligocene sediments rich in calcareous material. This depositional regime was characterized by an increased influx of terrigenous detritus into the Baltimore Canyon trough,

\footnotetext{
${ }^{1}$ Poag, C. W., Watts, A. B., et al., Init. Repts. DSDP, 95: Washington (U.S. Govt. Printing Office).

2 Address: Department of Geology, Texas A\&M University, College Station, TX 77843.
}

beginning sometime between the Oligocene and Miocene and continuing to this day.

The purpose of this study is to determine the sources of this terrigenous detritus and variations in the sources that may have occurred from the Miocene to the present. The techniques used to determine the sources are Fourier analysis of the shapes of quartz grains and scanning electron microscopy of quartz-grain surface textures.

\section{METHODS}

\section{Sample Base}

Twenty-seven samples from the upper Miocene through upper Pleistocene sediments of Subunits IA and IB were taken from cores recovered at Site 612. The average sample spacing for these samples was 3.5 $\mathrm{m}$. Forty-four samples from the upper Miocene through upper Pleistocene sediments of Subunits IA, IB, and IC were taken from cores from Site 613. The average sample spacing for this set of samples was $6.1 \mathrm{~m}$.

\section{Measurement of Grain Shape}

The purpose of this study was to determine the sources of relatively coarse-grained (i.e., sand and silt) detritus for the sediments of Unit I by analysis of grain shape. Because there is a strong relationship between the size and shape of sediment grains (Griffiths, 1967), it is necessary to restrict the analysis to a limited size fraction, but one that is more or less representative of the sediment as a whole. The analysis here has been restricted to the coarse silt fraction common throughout most of the sediments under study. Similarly, because there is a strong relationship between the composition and the shape of sediment grains, it is necessary to restrict the analysis to coarse silts of one composition (Griffiths, 1967). In this study, the analysis has therefore been restricted to quartz grains of coarse silt size.

A combination of mechanical and chemical techniques was used to isolate the coarse silt quartz fraction in each sample. Each sample was first disaggregated manually or with the aid of a sonic dismembrator, and then wet-sieved to isolate the coarse silt fraction. This fraction was then soaked in $50 \% \mathrm{HCl}$ for up to $30 \mathrm{~min}$., rinsed, soaked in $19 \%$ $\mathrm{HF}$ for 3 min., rinsed, and dried. The $\mathrm{HCl}$ and $\mathrm{HF}$ acids dissolve or etch any non-quartzose particles but do not affect the shapes of the quartz grains (Schultz, 1980). Finally, the sample was passed through a Franz isodynamic magnetic separator. In this manner, a split of coarse silt enriched in quartz grains was isolated from each sample. 
Shape analysis was chosen as the method to determine the Unit I sediment sources because it is known that different sources release quartz grains of any size with distinctive shape characteristics (Yarus, 1976; Przygocki, 1977; Wagoner and Younker, 1982; Mazzullo and Withers, 1984; Mazzullo and Crisp, 1984). Moreover, the shapes of coarse quartz silt grains, and thus the source-related information determinable from their shapes, are not altered to any great degree by abrasion during transport (Krumbein, 1942).

To read the record of source preserved in grain shape, a method is required for measuring grain shape and distinguishing grains with significantly different shape characteristics. The Fourier grain-shape technique (Ehrlich and Weinberg, 1970) is used in this study for this purpose. In this technique, the two-dimensional shape of a grain is measured by a Fourier series in closed form. Each grain's shape is represented by a series of terms, called "harmonics," each of the form $R n \cos (n \Theta-$ $\Phi n$ ), where $R n$ represents the "amplitude," or relative contribution, of the " $n$th harmonic," and the remainder concerns the phase angle of that harmonic. In general, the " $n$ th-harmonic amplitude" represents the relative shape contribution of an " $n$-leaved clover." Harmonic amplitudes are calculated for 24 harmonics, numbered 1 through 24 ; the observed shape of each grain is thus partitioned into a series of terms where the gross shape (elongation, triangularity, etc.) is measured by the amplitudes of the lower harmonics and increasingly finer-scaled roundness features are measured at higher harmonics.

The raw data needed to calculate the Fourier amplitudes for each grain are the $x-y$ coordinates of the edges of the maximum projection profile of the grains. To gather these data, a small split of prepared sample is mounted in glycerine on a glass slide and placed on a petrographic trinocular microscope. A TV camera mounted on this microscope views the microscopic field (loose grains mounted in glycerine) on the slide and transmits this to an image-analysis microcomputer system called ARTHUR II. This image-analysis system identifies the edge of a grain as pixel units, which are darker than the surrounding mounting medium, and digitizes between 200 and 1000 edge points on each grain. The system is controlled by the operator, who selects grains randomly for digitization; the operator ensures that only quartz grains are digitized and that the edges of each grain are digitized correctly. Approximately 200 coarse quartz silt grains were digitized from each sample in this manner.

After the Fourier amplitudes have been calculated from the raw edge-point data, harmonic amplitude data are graphically presented for each sample in the form of histograms, called shape frequency distributions, which for each of the 24 harmonics plot frequency of occurrence as a function of amplitude. Shape frequency distributions of samples from a basin are usually complexly polymodal, indicating mixtures, in varying proportions, of grains with different provenance histories. "Unmixing," or determining the number of grain-shape populations present in a sample set and their relative contributions to each sample, is achieved by application of a Q-mode algorithm called EXTENDED CABFAC EXTENDED QMODEL (Full et al., 1981). This algorithm is applied to the shape frequency distributions of those harmonics containing more variabillity between samples, and hence more information about provenance history, than other harmonics.

The location of the information-rich harmonics is determined by a relative entropy analysis of the shape frequency distributions (Full et al., 1984). "Relative entropy" is defined as the ratio of the calculated sample entropy to the maximum possible entropy; low relative entropies for the shape frequency distributions of a given harmonic indicate a higher degree of contrast between these shape frequency distributions than do high relative entropies. Among all the harmonics, those with the lowest relative entropy values have the highest potential for a clear, umambiguous solution by the Q-mode algorithm.

\section{ANALYSIS OF GRAIN-SHAPE DATA}

After the Fourier amplitude values had been calculated and the shape frequency distributions constructed for each of the samples from Unit I, these shape frequency distributions were analyzed using the relative entropy method (Full et al., 1984). This analysis indicated that the lowest relative entropy values, and hence the greatest amount of intersample variability, occur at harmonics $15,16,18,19,20$, and 21 , all of which measure various aspects of grain roundness (Fig. 1). Analysis of the shape frequency distributions for these harmonics with the "unmixing" algorithm EXTENDED CABFAC EXTENDED QMODEL indicates that a minimum of $94 \%$ of the variability occurring between samples at each of these harmonics can be accounted for by considering each sample to be a mixture, in varying proportions, of two types of grain shape.

The representative shape frequency distributions for the two types at harmonics $15,16,18,19,20$, and 21 are shown in Figure 2. The type-1 grain shape is characterized by a high proportion of coarse quartz silt grains with low amplitude values at these harmonics; type 2 is characterized by a high proportion of coarse quartz silt grains with high amplitude values at these same harmonics. In general, therefore, shape type 1 is characterized by a high proportion of relatively rounded grains, whereas shape type 2 is characterized by a high proportion of relatively angular grains.

If these two grain-shape types represent coarse quartz silt grains derived from different source terranes, the general nature of these source terranes can be determined by examining the surface textures of the coarse quartz silt grains with a scanning electron microscope (Mazzullo et al., 1984). Representative samples containing high proportions of either grain-shape type were selected for this purpose. For each sample, the coarse silt fraction was isolated by sieving and then boiled in hydrochloric acid for approximately $10 \mathrm{~min}$. A small split of each prepared sample was then mounted on an aluminum plug, coated with a gold-palladium alloy, and then examined on a JEOL JSM-25U scanning electron microscope. Approximately 20 randomly chosen grains from each sample were examined in this manner.

The major cause of the well-rounded shapes of the coarse quartz silt grains associated with grain-shape type 1 appears to be the precipitation of several smooth sheets of authigenic silica (Fig. 3A). Such surface textures are typical of grains which have been subjected to repeated prolonged chemical weathering in soils, and are commonly found on quartz grains derived from the poorly consolidated coastal plain strata that crop out along the northeastern U.S. continental margin (Mazzullo et al., 1984). Thus, it is concluded that the type-1 grain shape

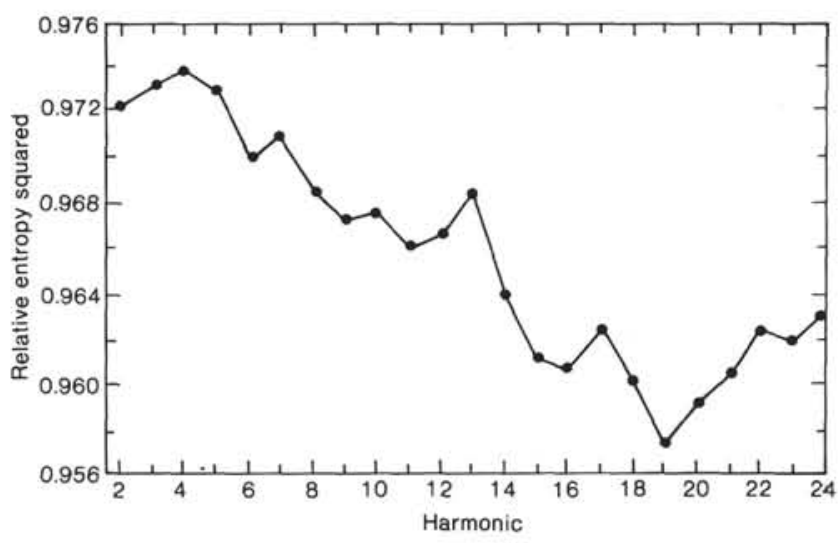

Figure 1. Relative entropy values for harmonics 2 through 24 . 


\section{Harmonic}

Type-1 grain shape

$\mathrm{H} 15$

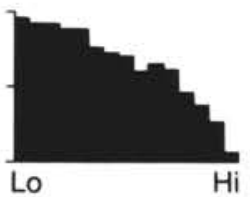

H16
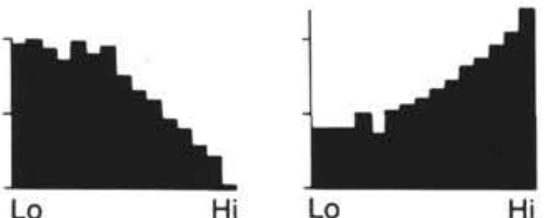

$\mathrm{H} 18$
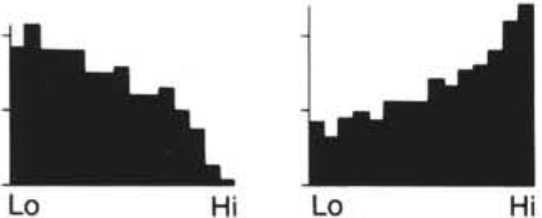

H19
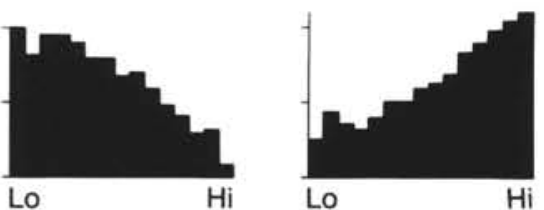

$\mathrm{H} 2 \mathrm{O}$
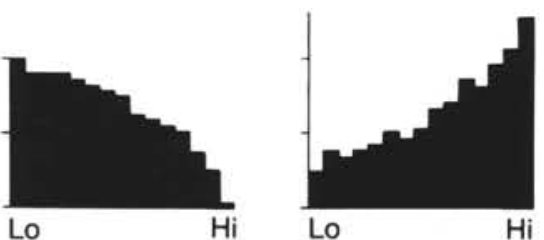

$\mathrm{H} 21$
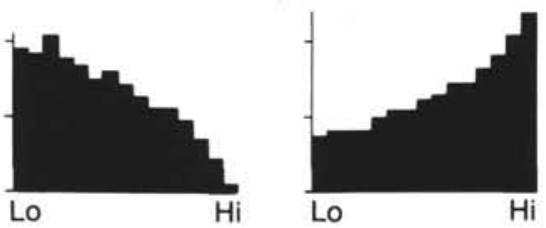

Amplitude

Figure 2. Shape frequency distributions for harmonics 15, 16, 18, 19, 20 , and 21 for the two grain-shape types. Increasing amplitude value signifies increasing angularity of particles.

represents coarse quartz silt grains derived from the Cretaceous and Tertiary sediments that crop out along the eastern U.S. seaboard and on the New Jersey continental shelf and slope. Sediments from the eastern seaboard area were presumably transported to the New Jersey shelf edge by large rivers such as the Delaware and Hudson, as well as by the numerous smaller coastal plain rivers of New Jersey, and to the deeper-water slope and rise environments of Sites 612 and 613 by deep-water sedimentation processes (debris flows, turbidity currents, etc.). Sediments from the local slope sources were presumably transported to their deposition site by deep-water sedimentation processes alone.

On the other hand, the most distinctive grain morphology associated with the type- 2 grain shape is angular quartz grains with well-formed euhedral and subhedral overgrowth forms (Fig. 3B). Such features are typical of grains derived from sedimentary and metasedimentary rocks (Mazzullo et al., 1984). Often, the surfaces of the overgrowths on these grains contain small fracture features typical of grains liberated from a well-lithified rock by mechanical weathering processes (Higgs, 1979). These fracture features can often be confused with fractures produced on quartz grains by glacial grinding; on glacially transported grains, however, fracture features are usually much larger, and cover greater portions of grain surfaces, than those observed on the angular grains associated with the type- 2 grain shape. In fact, those sur-

A

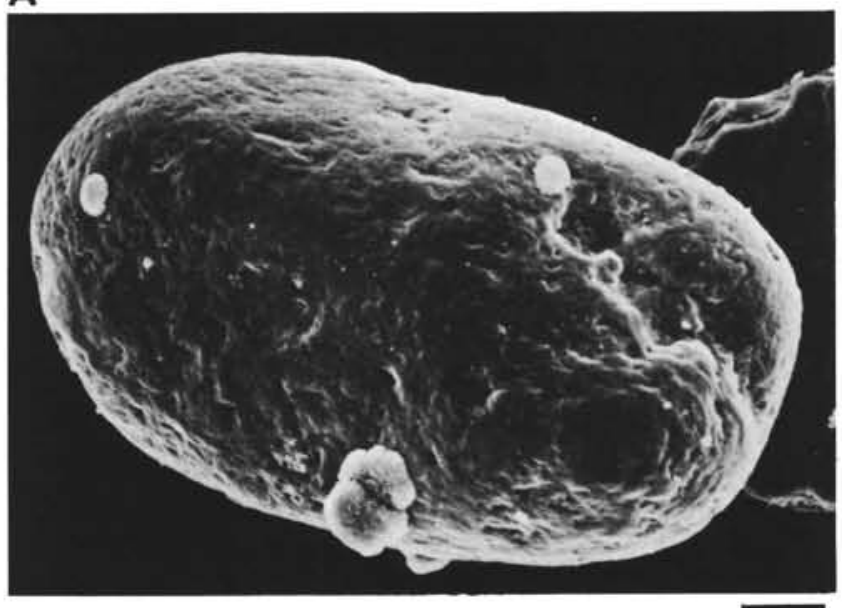

B

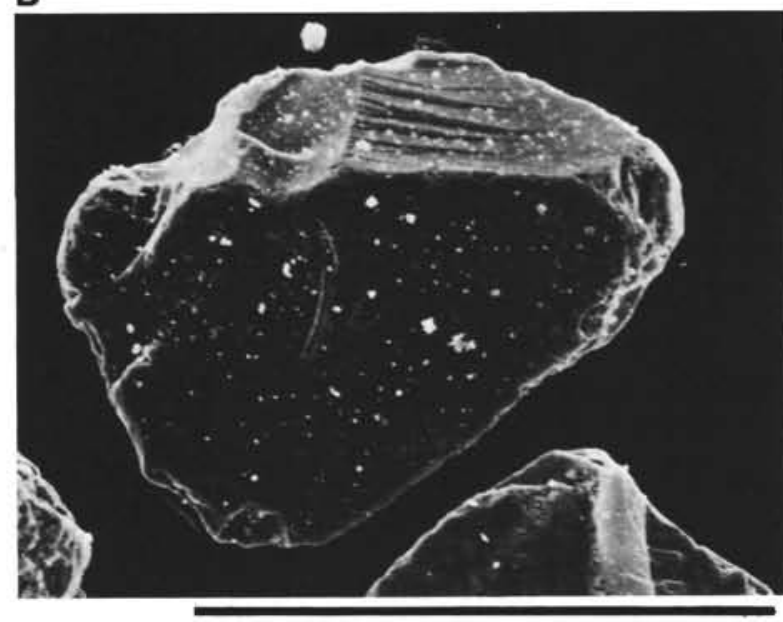

Figure 3. Representative quartz silt grains for the two grain-shape types. A. Well-rounded quartz silt grain with surface smoothed by precipitation of numerous sheets of authigenic silica (bar represents 10 $\mu \mathrm{m})$. B. Angular quartz silt grain with inherited overgrowth form and small fractures (bar represents $100 \mu \mathrm{m}$ ). 
face textures considered diagnostic of glacial transportlarge and numerous conchoidal, arc-shaped, and steplike fractures, breakage blocks, comminution debris, etc. (Mazzullo and Anderson, in press) - are not commonly found on the angular grains associated with grain-shape type 2.

It is concluded, therefore, that grain-shape type 2 represents coarse quartz silt grains derived from well-lithified sedimentary and metasedimentary rocks such as are exposed in the Appalachian Mountain region and surrounding areas. These sediments were presumably transported to the New Jersey shelf edge by a river system, such as the Hudson or Delaware, which drained large portions of the Appalachian Mountain region.

In a previous study of the sources of sand on the continental shelf between the Hudson Canyon and Cape Hatteras (Prusak, 1985), it was found that the two major sources of sand for that area were the unconsolidated Cretaceous and Tertiary strata of the eastern U.S. seaboard and the consolidated Paleozoic and Mesozoic sedimentary and metasedimentary rocks of the Appalachian Province. It was also found that glacially derived sand grains were not present in any great abundance in these shelf sands. Thus, the results derived from this Leg 95 provenance study of Unit I on the New Jersey slope and rise are consistent with other studies of sediment sources in updip shelf settings.

\section{VARIATIONS IN SEDIMENT SOURCES DURING THE LATE CENOZOIC}

The percentage of each grain-shape type present in each sample from Unit $I$ is plotted against sample depth in Figures 4 and 5. These figures show that the relative proportions of "coastal plain" sediment (represented by type-1 grain shape) and "Appalachian" sediment (represented by type- 2 shape) vary in a regular manner throughout Unit I, and that a distinct change in the sources of detrital sediment occurred at some time in the Pleistocene (the time of deposition of Unit I) at both Site 612 and Site 613.

At Site 612, on the New Jersey upper continental slope, Unit I can be divided into two distinct intervals. The boundary between these intervals occurs between Sections 1 and 3 in Core 612-4, a few meters above the upper Pliocene/upper Pleistocene contact. It is in this same core that a major lithologic change occurs in Unit I as well. Below this core, the sediment consists of interbedded mud and glauconitic sand deposited at relatively low rates ( 15 to $20 \mathrm{~m} / \mathrm{m}$.y.), whereas above this core the sediment consists of homogeneous burrowed mud deposited relatively rapidly ( $>80 \mathrm{~m} / \mathrm{m}$.y.; see Site 612 chapter, this volume).

The sediment in the lower interval of Unit I is usually dominated by high proportions of Appalachian sediment (type-2 grain shape), particularly in the deepest cores. The relative proportion of coastal plain sediment (type1 grain shape) is low at the base of this interval but gradually increases upsection to subequal proportions. The sediment in the upper interval, on the other hand, always contains large amounts of coastal plain sediment and relatively minor ( 11 to $35 \%$ ) proportions of Appalachian sediment.

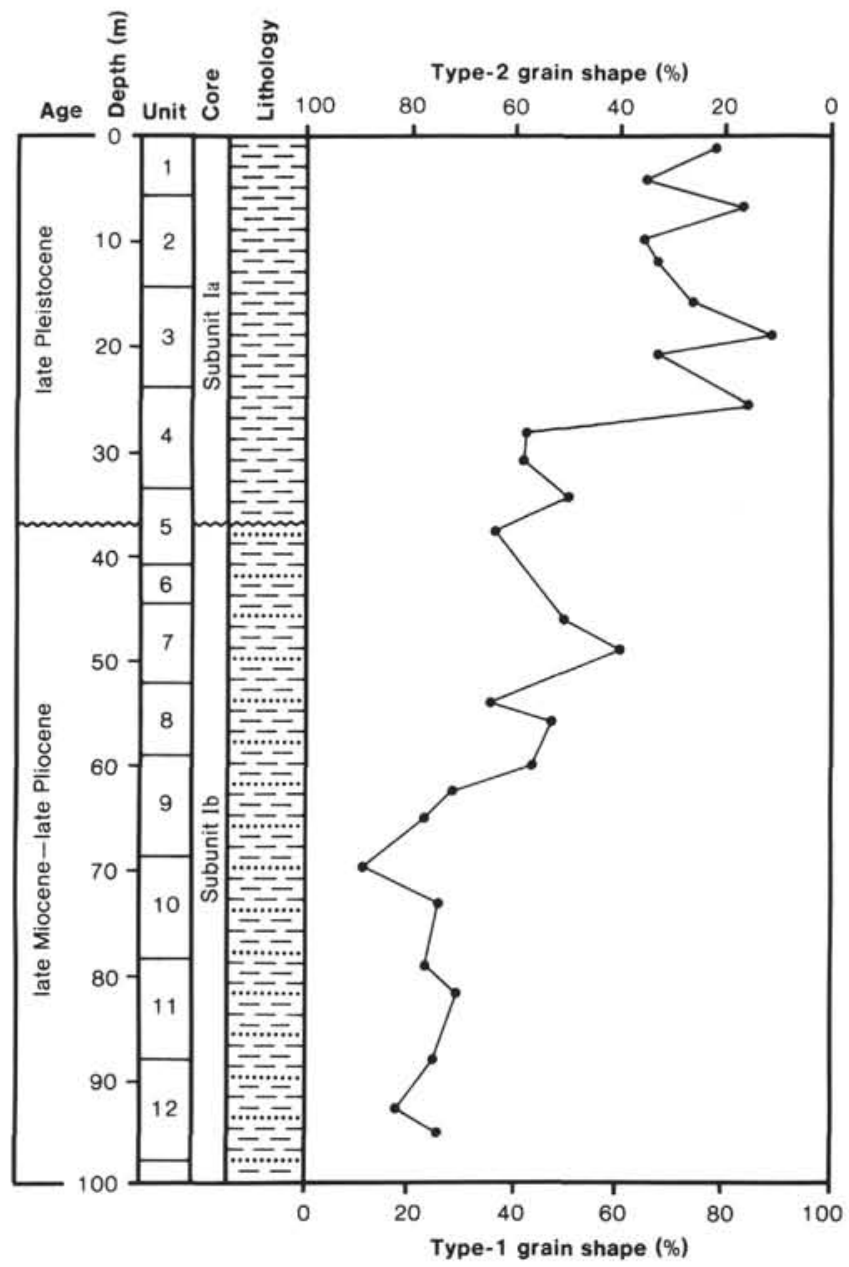

Figure 4. Stratigraphic section for Unit I, Site 612, showing the distribution of the two grain-shape types.

At Site 613, on the New Jersey continental rise, Unit I can again be divided into two distinct intervals. In this instance, however, the boundary between the intervals occurs precisely at the upper Pliocene/lower Pleistocene contact in Core 613-11. As in the previous instance, the sediment in the lower interval (which conforms to Subunit Ic) is usually dominated by high proportions of Appalachian sediment (type-2 grain shape). The proportion of Appalachian sediment increases upward through the upper Miocene to lower Pliocene section in this lower interval and then decreases slightly within the upper Pliocene section. The sediment in the upper interval, which includes Subunits IB and IA, is again dominated by high proportions of coastal plain sediment.

In short, the Pleistocene Epoch witnessed an abrupt change in the source of clastic detritus for the Baltimore Canyon trough. Before this time, the major source of sediment was the lithified Paleozoic and Mesozoic sedimentary and metasedimentary rocks of the Appalachian region. After this time, the main source was the Tertiary and Cretaceous sediments of the New Jersey continental margin.

These patterns of grain-shape variation within Unit I in both cores indicate that during the late Miocene and Pliocene a large river system such as the Hudson or Del- 


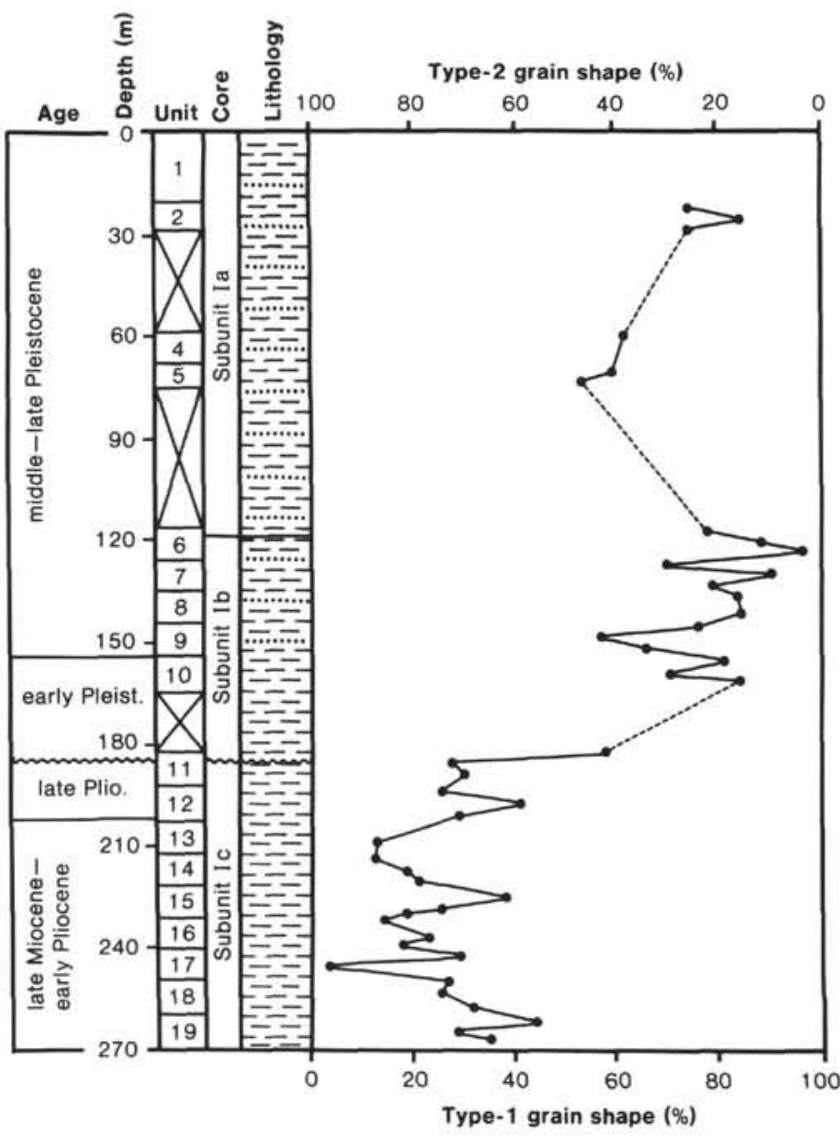

Figure 5. Stratigraphic section for Unit I, Site 613, showing the distribution of the two grain-shape types.

aware, draining the montane areas of Pennsylvania and/ or New York and New England, supplied "Appalachian" sediment to the New Jersey continental margin and ultimately to the upper slope and rise. During the Pleistocene, however, this river system stopped supplying sediment to the New Jersey continental margin (and to the two sites studied). Absent this source, the major sources of sediment to the sites for most of the Pleistocene were the Cretaceous and Tertiary sediments exposed on the New Jersey coastal plain and on the New Jersey continental shelf and slope.

Drastic changes in the depositional basins of fluvial sediments on the New Jersey continental margin are not unknown. Veatch and Smith (1939) and Kelling et al. (1975), for example, have shown that the mouth of the ancestral Hudson River migrated between the Hudson Canyon and the Baltimore Canyon during the Pleistocene, supplying sediments at various times to the numerous shelf-edge canyon systems on the New Jersey continental slope. Seismic profiles in the vicinity of the Baltimore Canyon Trough show that a large fluvial-deltaic system existed in this area during the middle Miocene to Pliocene but was not present in the Pleistocene (Poag, 1984, 1985). It is probable that this same fluvial-deltaic system served as a conduit for Appalachian sediment to the New Jersey continental slope during the late Miocene and Pliocene, and that the change in sediment provenance which occurs in the Pleistocene section of Unit I coincides with the migration of this fluvial-deltaic system to other parts of the eastern U.S. continental margin.

\section{REFERENCES}

Ehrlich, R., and Weinberg, B., 1970. An exact method for the characterization of grain shape. J. Sediment. Petrol., 40:205-212.

Full, W., Ehrlich, R., and Kennedy, S., 1984. Optimal configuration and information of sample data generally displayed as histograms of frequency plots. J. Sediment. Petrol., 54:117-126.

Full, W., Ehrlich. R., and Klovan, J. E., 1981. EXTENDED QMODEL: objective definition of external end members in the analysis of mixtures. J. Math. Geol., 13:327-341.

Griffiths, J., 1967. The Scientific Method in the Analysis of Sediments: New York (McGraw-Hill, Inc.).

Higgs, R., 1979. Quartz-grain surface features of Mesozoic-Cenozoic sands from the Labrador and western Greenland continental margins. J. Sediment. Petrol., 49:599-610.

Kelling, G., Sheng, H., and Stanley, D. J., 1975. Mineralogical composition of sand-sized sediment on the outer margin off the MidAtlantic states: assessment of the influence of the ancestral Hudson and other fluvial systems. Geol. Soc. Am. Bull., 86:853-862.

Krumbein, W. C., 1942. The effects of abrasion on the size, shape and roundness of sedimentary particles. J. Sediment. Petrol., 11:64-72.

Mazzullo, J., and Anderson, J., in press. Grain shape and surface texture characteristics of basal till and glacial marine sand, Ross Ice Shelf: Fourier grain shape analysis. In Marshall, J. (Ed.), Characterization and Quantification of Surface Features on Clastic and Pyroclastic Particles: New York (John Wiley and Sons).

Mazzullo, J., and Crisp, J. A., 1984. Quartz-grain shape: a record of the source of fine-grained sediments. Geomarine Lett., 4:197-202.

Mazzullo, J., Ehrlich, R., and Hemming, M. A., 1984. Provenance and areal distribution of late Pleistocene and Holocene quartz sand on the southern New England continental shelf, J. Sediment. Petrol., 54:1335-1348.

Mazzullo, J., and Withers, K. D., 1984. Sources, distribution and mixing of late Pleistocene and Holocene sands on the South Texas continental shelf. J. Sediment. Petrol., 54:1317-1334.

Poag, C. W., 1984. Neogene stratigraphy of the submerged U.S. Atlantic margin. Paleogeogr., Paleoclimatol., Paleocecol., 47:103-127. 1985. Depositional history and stratigraphic reference section for central Baltimore Canyon Trough. In Poag, C. W. (Ed.), Geologic Evolution of the United States Atlantic Margin: New York (Van Nostrand Reinhold), pp. 217-263.

Prusak, D., 1985. Sources and distribution of sand on the Mid-Atlantic continental shelf between the Hudson Canyon and Cape Hatteras [M. S. thesis]. Texas A\&M University, College Station.

Pryzygocki, R., 1977. Identification of sediment in a fluvial network, North Carolina Blue Ridge: Fourier grain shape analysis [M. S. thesis]. University of South Carolina, Columbia.

Schultz, D. J., 1980. The effect of hydrofluoric acid on quartz shapeFourier grain shape analysis. J. Sediment. Petrol., 50:644-645.

Veatch, A. C., and Smith, P. A., 1939. Atlantic submarine valleys of the United States and the Congo submarine valley. Spec. Pap. Geol. Soc. Am., 7.

Wagoner, J. L., and Younker, J. L., 1982. Characterization of alluvial sources in the Owens Valley of eastern California using Fourier shape analysis. J. Sediment. Petrol., 52:209-214.

Yarus, J., 1976. Bedrock identification by Fourier grain shape analysis of saprolitic quartz, South Carolina Piedmont [M. S. thesis]. University of South Carolina, Columbia.

Date of Initial Receipt: 25 April 1985

Date of Acceptance: 2 August 1985 